\title{
Penyelesaian Hukum Pelanggaran Pemilu Dalam Pemilihan Kepala Daerah Kota Pekanbaru Berdasarkan Undang- Undang Nomor 10 Tahun 2016
}

\author{
Oleh: Andrizal" \\ Dosen Fakultas Hukum Lancang Kuning \\ Jalan Yos Sudarso Km 8, Rumbai, Kota Pekanbaru, Indonesia
}

\begin{abstract}
Abstrak
Tujuan penelitian ini untuk: Pertama, menjelaskan penyelesaian hukum pelanggaran pemilu dalam pemilihan kepala daerah Kota Pekanbaru berdasarkan Undang-Undang Nomor 10 Tahun 2016? Kedua, menjelaskan hambatan penyelesaian hukum pelanggaran pemilu dalam pemilihan kepala daerah Kota Pekanbaru? Ketiga, menjelaskan upaya yang dilakukan dalam mengatasai hambatan penyelesaian hukum pelanggaran pemilu dalam pemilihan kepala daerah Kota Pekanbaru. Metode penelitian yang digunakan penelitian hukum sosiologis. Hasil penelitian ini dapat dijelaskan dalam konteks Pemilukada Kota Pekanbaru, penyelesaian hukum pelanggaran pemilu diselesaikan oleh Panwas Kota Pekanbaru terhadap putusan KPU Kota Pekanbaru yang mendiskualifikasi salah satu pasangan calon.Simpulan penelitian ini: Pertama, penyelesaian hukum pelanggaraan pemilu dalam Pemilukada Kota Pekanbaru selain dari pada tindak pidana pemilu diselesaikan oleh KPU dan Panwaslu. Setiap ada temuan dan laporan dari masyarakat sesegera mungkin ditindaklanjuti oleh Panwaslu dan hasil kajiannya bentuk rekomendasi disampaikan kepada KPU. Hasil rekomendasi tersebut segera diambil tindakan apakah pelanggaran administrasi atau ada unsur tindak pidana pemilu didalamnya. Kedua, hambatan penyelesaian hukum pelanggaran pemilu dalam Pemilukada Kota Pekanbaru adalah perangkat peraturan perundang-undangan yang tumpang-tindih kewenangan KPU dan Panwaslu. Ketiga, upaya yang dilakukan dalam penyelesaian hukum pelanggaraan Pemilukada Kota Pekanbaru dengan cara membangun koordinasi yang baik sesama unsur penyelenggara pemilu, yaitu KPU, Panwas dan Bawaslu.
\end{abstract}

Kata Kunci: Pemilukada, Pelanggaran, Kota Pekanbaru.

*Penulis korespondensi e-mail: andrizal2017@gmail.com 


\begin{abstract}
The purpose of this study is to: First, explain the legal settlement of electoral violations in the election of the regional head of Pekanbaru City based on Law No. 10 of 2016? Second, explain the obstacles of legal settlement of election violation in the election of regional head of Pekanbaru City? Third, explaining the efforts made in overcoming obstacles to the legal settlement of election violations in the regional head election Pekanbaru City. The research method used is sociological law research. The results of this study can be explained in the context of the General Election of Pekanbaru City, the settlement of election violation law is settled by Panwas Pekanbaru City against the decision of Pekanbaru City KPU disqualifying one of the candidate pairs. The conclusions of this research are: First, legal settlement of election violation in Pemilukada of Pekanbaru City other than from election crime is completed by KPU and Panwaslu. Any findings and reports from the community as soon as possible are followed up by the Panwaslu and the results of its review of recommendations are submitted to the KPU. The result of such recommendation shall be taken promptly whether the violation of administration or any element of election crime therein. Second, the obstacles to the settlement of election violation law in Pemilukada Pekanbaru is a set of laws and regulations that overlap the authority of KPU and Panwaslu. Third, the efforts made in the legal settlement of violations Pemilukada Pekanbaru by way of building good coordination among election organizers, namely KPU, Panwas and Bawaslu.
\end{abstract}

Keywords: Pemilukada, Violation, Pekanbaru City. 


\section{Pendahuluan}

Indonesia memulai kembali proses desentralisasi pada tahun 2001 yang sebelumnya terhenti sejak digagas pertama kali tahun 1933 oleh Muhammad Hatta dalam tulisannya "Autonomi dan Centralisasi dalam Partai" dan selama ini kebijakan desentralisasi memberikan banyak warna terhadap perjalanan berbangsa dan bernegara di Indonesia. Proses desentralisasi itu sendiri merupakan proses yang sangat penting dan menentukan masa depan Indonesia. Keberhasilan dan kegagalan kebijakan ini akan memberikan dampak yang sangat besar terhadap berbagai aspek kehidupan bangsa terutama kehidupan demokrasi di Indonesia. ${ }^{1}$

Demokrasi menurut Diamond harus dipandang sebagai fenomena yang berkelanjutan. Dari perspektif ini, masa depan demokrasi tiada henti, elemen-elemen emokrasi akan muncul dan berkembang dalam berbagai tingkatan dan tahapan dengan tingkat kecepatan yang berbeda-beda di setiap negara. Perubahan demokrasi juga bergerak menuju arah yang berbeda, bisa menjadi semakin demokratik dan bisa juga semakin tidak demokratik.
Oleh karena itu, demokrasi harus selalu diperkuat baik dengan penguatan institusi maupun penguatan civil society. ${ }^{2}$

Tantangan bagi penguatan de mokrasi atau konsolidasi demokrasi dengan memberikan akses demokrasi kepada masyarakat dan pembentukan serta penguatan institusi-institusi demokrasi. Dititik inilah desentralisasi dengan perwujudan otonomi daerah memiliki peran yang sangat penting dalam konsolidasi demokrasi. Peran desentralisasi dalam konsolidasi demokrasi tersebut berasal dari adanya proses demokrasi yang memotivasi otoritas lokal dalam menjawab aspirasi dan kebutuhan konstituennya. Selain itu, salah satu pemikiran diterapkannya desentralisasi adalah institusi demokrasi lokal akan lebih memahami dan merespon aspirasi lokal karena jika dilihat dari asfek jarak institusi dan masyarakat lokal yang dekat, mereka memiliki akses yang lebih baik terhadap informasi

Demokratisasi di Indonesia kemudian diperkuat dengan adanya pemilihan kepala daerah secara langsung atau yang lebih dikenal dengan Pilkada mulai tahun 2005 (istilah sekarang Pemilukada) dan

${ }^{1}$ Mohd. Hatta dalam Zuli Afrianto,Analisis Peran Aktor Pada Pemilu Kepala Daerah Kota Bandar Lampung Periode 2010-2015, Tesis, Magister IImu Pemerintahan, Program Pascasarjana Magister IImu Pemerintahan Fakultas IImu Sosial dan IImu Politik, Universitas Lampung, 2013, hlm. 45.

${ }^{2}$ Diamond dalam Refki Mukhliza, Pemilihan Umum Kepala Daerah di Kabupaten Pasama Tahun 2010, Artikel, Program Magister IImu Hukum Pascasarjana Universitas Bung Hatta Padang, 2014, hlm. 8. 
geliat Pemilukada akhir-akhir ini semakin dinamis. Pemilukada merupakan institusi demokrasi lokal yang penting karena dengan Pemilukada, kepala daerah yang akan memimpin daerah dalam mencapai tujuan desentralisasi akan terpilih melalui tangan-tangan masyarakat lokal secara langsung.

Salah satu prasyarat negara demokrasi, alangkah baiknya jika pengadilan khusus Pemilukada serentak merupakan bagian terpenting dalam mengawal proses demokrasi. Karena peradilan khusus pemilu merupakan sebuah ius constituendum (cita hukum) yang tujuannya untuk memproteksi hak konstitutional warga negara dan peserta pemilihan umum, untuk memberikan ruang hukum kepada pihak-pihak yang dirugikan dalam penyelenggaraan Pemilukada serentak untuk mendapatkan kepastian hukum dalam kehidupan negara demokrasi, sekaligus sebagai upaya untuk mempercepat penyelesaian sengketa atau kasuskasus selama proses pemilihan umum berlangsung.

Gagasan pengadilan khusus pemilu sebenarnya merupakan salah satu komponen terpenting dalam asas-asas penyelengaran pemilu diantaranya "kepastian hukum". Dalam konteks kepastian hukum, antara penyelenggara pemilu, pengawas pemilu, pemantau pemilu dan peserta pemilu menerima secara baik dari proses tahapan, program dan jadwal waktu penyelenggaran pemilu. Apabila ada pihak-pihak yang belum puas atas hasil kerja yang diberikan oleh Komisi Pemilihan Umum (KPU) sebagai penyelenggara pemilu, da- pat mengajukan sengketanya di pengadilan khusus pemilu.

Contoh kasus yang pernah menjadi persoalan misalnya, pada Pemilihan Kepala Daerah Serentak tahap II, yaitu pada Pemilihan Wali Kota Pekanbaru pada tahun Bulan Februari tahun 2017 yang dilaksanakan di Kota Pekanbaru Riau, ada 1 (satu) pasangan calon peserta pemilu dibatalkan sebagai peserta pemiluPilkada serentak oleh KPU Kota Pekanbaru. Pembatalan tersebut dilakukan saat hari-hari terakhir penetapan calon peserta Pemilhan Kepala Daerah (Pemilukada) serentak. KPU Kota Pekanbaru beralasan bahwa peserta yang bersangkutan tidak memenuhi persyaratan kesehatan sehingga tidak lolos untuk untuk menjadi pasangan calonpeserta $\mathrm{Pe}$ milukada serentak, dengan seenaknya membatalkan pasangan calon tersebut.

Ketika pasangan calon tersebut mengajukan gugatan keberatan ke Badan Pengawas Pemilu (Bawaslu) Provinsi Riau, ternyata Keputusan Bawaslu membatalkan keputusan yang dikeluarkan oleh KPU Kota Pekanbaru, pada akhirnya pasangan calon tersebut dapat kembali ikut sebagai peserta Pemilukadaserentak.

Secara umum, perkara atau sengketa pemilu mencakup tiga ranah, yaitusengketa hasil pemilu, perkara pidana pemilu, dan sengketa administrasi pemilu. Apabila merujuk Undang-Undang Nomor 10 Tahun 2008 dan Undang-Undang Nomor 12 Tahun 2008, untuk sengketa hasil pemilu diselesaikan di Mahkamah Konstitusi (MK), sedangkan penyelesaian perkara 
pidana pemilu diselesaikan melalui Pengadilan Negeri (PN), sementara penyelesaian pelang - garan administrasi pemilu yang dilakukan oleh KPU pusat, provinsi dan kabupaten/kota berdasarkan laporan Bawaslu dan Panitia $\mathrm{Pe}$ ngawas Pemilu (Panwaslu).

Ketersediaan mekanisme penyelesaian sengketa untuk dua persoalan pertama tentunya sudah lebih dari cukup. Artinya, semua pemangku kepentingan telah diberikan ruang untuk menyelesaikan persoalan yang terjadi melalui MK dan peradilan umum. Sementara, pada ranah sengketa yang ketiga, masih terdapat kekosongan hukum yang dapat merugikan masyarakat maupun peserta pemilu. Salah satunya adalah persoalan administratif yang timbul karena diterbitkannya keputusan KPU pusat, provinsi atau kabupaten/kota yang merugikan peserta pemilu.

Kembali terhadap persoalan diatas, MK berpendapat bahwa MK tidak mempunyai kewenangan untuk memeriksanya. Sebab, sengketa tersebut merupakan sengketa administratif, bukan sengketa hasil pemilu yang menjadi kewenangan MK. Berdasarkan putusan MK, mengajukan gugatan sengketa administratif kepada Peradilan Tata Usaha Negara PTUN). Dalam putusan selanya, PTUN pun memutuskan bahwa juga tidak berwenang memeriksa dan mengadili perkara yang diajukan.Apabila perkara tersebut diajukan kepada peradilan umum, dapat dipastikan bahwa pengadilan umum pun tidak berwenang memeriksanya, karena wewenang pengadilan umum terkait dengan sengketa pidana pemilu bukan sengketa administratif sesuai dengan perkara tersebut.

Apabila semua semua pengadilan menyatakan tidak berwenang untuk memeriksa perkara tersebut, lalu untuk mempertahankan haknya sebagai peserta pemilu, kepada siapa seharusnya peserta pemilu ini dapat mengajukan keberatan atau gugatannya? Secara bersamaan apakah KPU pusat, provinsi atau kabupaten/kota merupakan institusi yang kebal dari gugatan terhadap keputusan yang dinilai merugikan hak konstitusional warga negara dan peserta pemilu? Bukankah persoalan diatas merupakan salah satu wujud tidak fair-nya pelaksanaan pemilu yang disebabkan tidak adanya ketersediaan mekanisme penyelesaian sengketa. ${ }^{3}$

Selain itu, terkait dengan munculnya kisruh seputar pemilu dapat dibagi menjadi faktor eksternal dan internal. Faktor eksternal terkait kinerja KPU yang tidak sesuai dengan harapan masyarakat dan Bawaslu yang cenderung tidak dapat berbuat maksimal dalam mengawasi jalannya pemilu dikarenakan Bawaslu tidak memiliki kewenangan untuk mengeluarkan sebuah keputusan yang bersifat eksekutorial.

Dari segi internal terkait persoalan moralitas KPU, Bawaslu dan para calon yang tidak sadar akan prinsip-prinsip demokrasi Moralitas KPU dan Bawaslu cenderung tidak

${ }^{3}$ Khairul Fahmi, Menimbang Pengadilan Khusus Pemilu. Majalah Mahkamah Konstitusi, Nomor 40, Mei 2011, hlm. 25. 
idealis terhadap prinsip-prinsip demokratisasi di Indonesia Kesadaran untuk mewujudkan general walfare bagi masyarakat Indonesia bukanlah sebuah kesadaran yang terlembagakan di KPU dan Bawaslu. Padahal, posisi dari pemilu sangat menentukan bagaimana pemerintahan Indonesia lima tahun kedepan. Begitupun para calon yang seolah melihat celah untuk mengajukan gugatan setiap mereka kalah, padahal banyak gugatan yang diajukan hanya berdasarkan hasrat tidak menerima kekalahan.

Alangkah eloknya gagasan pembentukan pengadilan khusus pemilu dalam revisi Undang-Undang Nomor 10 Tahun 2008 tentang Pemilu Anggota DPR, DPD dan DPRD, memasukkan draf pengadilan khusus pemilu ke dalam Rancangan Revisi Undang-Undang Nomor 10 Tahun 2008 oleh Dewan Perwakilan Rakyat (DPR). Wacana pembentukan Pengadilan Khusus Pemilu harus didorong terus lewat Komisi II DPR. Pemasalahan-permasalahan tindak pidana pemilu yang sekarang ini terjadi tidak diselesaikan begitu saja di MK, karena bukan ranah hukum MK menyelesaikan tindak pidana pemilu. Pembentukan pengadilan khusus pemilu dapat memberikan pencerahan hukum ketatanegaraan Indonesia. ${ }^{4}$

Apabila dibentuk pengadilan khusus pemilu ditingkat kota/kabupaten di tingkat pertama dan pengadilan tinggi khusus pemilu pada tingkat banding yang berkedudukan di ibu kota provinsi merupakan solusi tepat, dalam menangani setiap sengketa Pemilu di tingkat daerah, karena MK dalam kewenangannya hanya sebatas sengketa perselisihan hasil pemilu, bukan sengketa pidana pemilu dan administrasi pemilu pada proses tahapan, program dan jadwal waktu penyelenggaraan pemilu.

Dengan dibentuknya pengadilan khusus pemilu ditingkat pertama dan pengadilan tinggi khusus pemilu pada tingkat banding maka para pencari keadilan yang berasal di daerah luar jawa, tidak perlu berbondong-bondong ke lbu Kota Jakarta. Akantetapi, cukup di ibu kota kabupaten/kota atau provinsi yang akan menjadikan pengadilan khusus pemilu lebih efektif dan efisien dalam mengadili kasuskasus pemilu.

Pemikiran hukum pembentukan pengadilan khusus pemilu memang membutuhkan investasi yang cukup besar, akantetapi dilihat investasi hukum jangka panjang maka pengadilan khusus pemilu akan memberikan alternatif hukum dalam menangani kasus-kasus pemilu agar lebih cepat, murah dan mudah serta memberikan kepastian hukum kepada semua pihak. Pengadilan khusus pemilu merupakan salah satu komponen dasar terciptanya kepastian hukum menuju negara demokrasi yang

${ }^{4}$ Didik Ariyanto, Perlukah Dibentuk Pengadilan Khusus Pemilu dalam Sistem Demokrasihttp://didikariyanto.blogspot.com/2011/06/ pengadilan-khusus-pemilu.html, diakses pada 12 September 2017. 
berdasarkan Pancasila dan Undang-Undang Dasar (UUD) Tahun 1945 dibawah naungan Negara Kesatuan Republik Indonesia (NKRI) yang sudah diputuskan dalam sidang tahunan Majelis Permusyawaratan Rakyat (MPR) saat amandemen pertama tahun 1999, mengenai bentuk negara tidak akan diubah (sudah harga mati).

Penelitian hukum terkait Pemilukada sudah pernah diteliti oleh beberapa penulis lain. Arif Ramadhan Sypernah melakukan penelitian dalam bentuk skripsi. Dalam hasil penelitiannya disimpulkan ada 4 (empat) hal yang berimplikasi pada Undang-Undang Nomor 8 Tahun 2015 terhadap penyelesaian sengketa pemilihan kepala daerah di MK. Pertama, penumpukan perkara di MK. Kedua, waktu penyelesaian perkara perselisihan pemilihan kepala daerah hanya 45 hari yang diatur oleh undang-undang. Ketiga, waktu pengajuan permohonan perkara perselisihan hasil pemilihan kepala daerah paling lama 3 x 24 jam sejak diumumkan penetapan perolehan suara hasil pemilihan oleh KPU Provinsi dan KPU kabupaten/kota. Keempat, syarat permohonan pengajuan gugatan, yaitu selisih perolehan suara antara pemohon dan pasangan lainnya paling banyak sebesar 2 persen. Kemudian ada 3 (tiga) hal yang beri- mplikasi pada putusan yang dikeluarkan MK terhadap penyelesaian sengketa hasil pemilihan kepala daerah oleh MK. Pertama, berimplikasi pada MK itu sendiri karena setiap kebijakan atau putusan yang dikeluarkan oleh MK sangat menentukan kepercayaan masyarakat publik terhadap lembaga tersebut. Kedua, akan berimplikasi bagi pasangan calon yang bersengketa yang disebut para pihak dan juga pada KPU daerah setempat yang disebut sebagai termohon. Ketiga, berimplikasi bagi daerah setempat yang bersengketa. $^{5}$

Herdi Munte Mirza Nasution dan kawan - kawan ,dalam penelitiannya menjelaskan rasionalisasi atau alasan pertimbangan adanya norma hukum penyelesaian sengketa administras Pemilukada yang diatur dalam Undang-Undang Nomor 1 Nomor 8 Tahun 2015 tentang Perubahan Undang-Undang Nomor 1 tahun 2015 tentang Penetapan Peraturan Pemerintah Pengganti Undang-Undang Nomor 1 Tahun 2014 menjadi undang-undang, memang sudah tepat dan dapat diterima secara logis. Hal ini didukung dasar pertimbangan logika yang memiliki legitimasi keberlakuan, yaitu pertimbangan yang bersifat filosofis, yuridis, sosiologis dan politis.

${ }^{5}$ Arif Ramadhan Sy, Implikasi Undang-Undang Nomor 8 Tahun 2015 tentang Perubahan Atas Undang-Undang Nomor 1 Tahun 2015 tentang Penetapan Peraturan Pemerintah Pengganti Undang-Undang Nomor 1 Tahun 2014 tentang Pemilihan Gubernur, Bupati, dan Walikota Menjadi Undang-Undang Terhadap Penyelesaian Sengketa Hasil Pemilihan Kepala Daerah di Mahkamah Konstitusi, Implikasi Undang-Undang Nomor 8 Tahun 2015 tentang Perubahan Atas Undang- 
Dasar pertimbangan logis tersebut bertujuan untuk menjamin hak-hak warga negara dalam mencari keadilan (acces to justice) dan perlindungan hukum bagi war-ga negara sebagai syarat unsur negara hukum yang berasaskan Pancasila. Adapun salah satu tujuan dibentuk dan diberlakukannya norma hukum penyelesaian sengketa Pilkada adalah untuk mencapai tujuan hukum dalam arti luas dan keadilan pemilu (electoral justice) dalam arti sempit.

Herdi Munte Mirza Nasution dan kawan-kawan menjelaskan putusan Bawaslu provinsi dan Panwas kabupaten/kota menurut undang-undang sangat strategis dan menentukan. Apabila ada keputusan tata usaha negara (KTUN) yang dikeluarkan oleh KPU provinsi atau KPU kabupaten/kota yang merugikan kepentingan hukum warga negara atau peserta pemilihan, wajib hukumnya terlebih menempuh upaya administrasi kepada Bawaslu provinsi dan Panwas kabupaten/kota disebut banding administrasi sengketa Pemilukada. Putusan majelis banding administrasi merupakan terakhir dan mengikat (final and binding) yang bermakna terhadap putusan tersebut tidak ada lagi upaya hukum dan memiliki nilai eksekutorial (wajib dilaksanakan) oleh penyelenggara pemilu atau para pihak. Hakikat putusan final dan mengikat mengandung makna, yaitu mewujudkan kepastian hukum, pengawas pemilihan sebagai pemutus akhir sengketa dan juga putusan itu sebagai alat pengendali sosial (a tool of social control).

\section{Terakhir Herdi Munte Mirza Nasution dan kawan-kawan} menambahkah metode penyelesaian sengketa yang tepat dan terukur sangat menentukan kualitas penegakan norma hukum penyelesaian sengketa yang putusan hukumnya final dan mengikat. Dari aspek hukum materil (norma undang-undang) dan formal (hukum acara/produral) maka belum ditemukan adanya parameter atau batu uji yang terukur untuk dijadikan standar penilaian atau pengujian yang digunakan oleh Bawaslu provinsi dan Panwas kabupaten/kota dalam melakukan pengujian objek sengketa sesuai dengan prinsipprinsip hukum. Prinsip hukum dalam arti luas adalah prinsip hukum yang berlaku umum dan prinsip hukum dalam arti sempit adalah sesuai asas penyelenggaraan pemilu berdasarkan undang-undang. ${ }^{6}$

Yusri Munaf dalam penelitiannya menyimpulkan pelaksanaan Pemilukada serentak jelas berimplikasi terhadap perkembangan demokrasi di Indonesia.Implikasi tersebut dapat dilihat dari dinamika yang terjadi pada tatanan kebijakan yang telah ditetapkan menjadi Undang-Undang Nomor 8 Tahun 2015 tentang

\footnotetext{
${ }^{6}$ Herdi Munte Mirza Nasution et.al. Penyelesaian Sengketa Administrasi Pemilihan Kepala Daerah Berdasarkan Undang-Undang Nomor 8 Tahun 2015 tentang Pemilihan Gubernur Bupati dan Walikota (Studi Putusan Sengketa Administrasi Pemilihan Walikota dan Wakil Walikota di Panwas Kota Pematangsiantar Tahun 2015, USU Law Journal, Volume 5, Nomor 1, Januari 2017,hlm.169.
} 
Pemilihan Gubernur, Bupati dan Walikota sebagai dasar hukum pelaksanaan Pilkada secara langsung dan serentak di Indonesia. Implikasi Pemilukada serentak sebagai sebuah kebijakan yang dikeluarkan pemerintah dalam perkembangan demokrasi di Indonesia. Oleh karena itu, harapan besar bagi pelaksanaan Pemilukada serentak sebagai media politik yang memiliki posisi strategis sebagai pintu gerbang pembangunan di daerah yang berhasil dan bermanfaat bagi masyarakat. Ekses-ekses negatif harus disikapi dengan cermat, kritis dan arif, sehingga dapat menemukan solusi yang terbaik untuk membangun suatu sistem penyelenggaraan Pemilukada serentak yang efektif dan akuntabel bagi terbangunnya suatu pemerintahan daerah yang akuntabel dan amanah bagi seluruh warga masyarakat daerah. ${ }^{7}$

Zahirman, hasil penelitiannya menjelaskan bahwa banyak terjadi pelanggaran yang berkaitan dengan asas jujur dalam pelaksanaan pemilihan umum Walikota Pekanbaru, terutama oleh pihak pelaksana, yaitu KPU Kota Pekanbaru dan Panwaslu Kota Pekanbaru. Adapun bentuk pelanggaran, seperti pelaksanaan kampanye diluar jadwal dan menggunakan fasilitas negara, per- usakan atribut pemilu (kotak suara) dan pemalsuan dokumen pemilu, pencetakan surat suara tidak berdasarkan pada jumlah pemilih tetap dan ditambah paling banyak $2,5 \%$ dari jumlah pemilih tersebut, surat pemberitahuan waktu dan tempat pemungutan suara (undangan pemilih) yang tidak mencantumkan nomor induk kependudukan, kotak suara ditemukan dalam kondisi rusak dikantor KPU, daftar pemilih tetap ganda, serta pelanggaran kode etik oleh anggota Panwaslu. $^{8}$

Bila ditelaah penelitian terdahulu tersebut jelas tidak ada kaitannya dengan penyelesaian hukum pelanggaran pemilu dalam Pemilukada Kota Pekanbaru berdasarkan Undang-Undang Nomor 10 Tahun 2016. Oleh karena itu, penelitian ini merupakan sesuatu yang baru atau berbeda dengan penelitian terdahulu (novelty). Adapun permasalahan yang dibahas dalam penelitian ini: Pertama, bagaimanakah penyelesaian hukum pelanggaran pemilu dalam pemilihan kepala daerah Kota Pekanbaru berdasarkan Undang-Undang Nomor 10 Tahun 2016?Kedua, apa hambatan penyelesaian hukum pelanggaran pemilu dalam pemiliha kepala daerah Kota Pekanbaru?

${ }^{7}$ Yusri Munaf, Implikasi Pemilihan Kepala Daerah Serentak Pada Tahun 2016 Dalam Perkembangan Demokrasi di Indonesia, Asian Journal of Environment, Volume. 1, Issue 1, September 2017, hlm. 198-199.

${ }^{8}$ Zahirman, Penerapan Asas Jujur Dalam Pelaksanaan Pemilihan Umum Walikota Pekanbaru ditinjau dari Undang-Undang Nomor 32 Tahun 2004, Jurnal PPKN \& Hukum, Volume, 10, Nomor 1, April 2015, hlm. 1. 
Ketiga, apa upaya yang dilakukan dalam mengatasai hambatan penyelesaian hukum pelanggaran pemilu dalam pemilihan kepala daerah Kota Pekanbaru? Hasil penelitian ini diharapkan dapat memberikan manfaat berupa sumbang saran dan dapat dijadikan bahan kajian lebih lanjut untuk melahirkan berbagai konsep keilmuan yang pada gilirannya dapat memberikan andil bagi perkembangan ilmu hukum tata negara Indonesia demi tercapainya negara hukum yang adil dan demokratis. Memberikan masukan kepada instansi terkait untuk melakukan evaluasi mengenai hal-hal yang menjadi penghambat dalam penyelesaian hukum pelanggaran Pemilukada.

\section{Metode Penelitian}

\section{Jenis penelitian}

Jenis penelitian ini adalah penelitian hukum Sosiologis. Penelitian hukum sosiologis menurut Badan Pembina Hukum Nasional (BPHN) lebih diarahkan pada suatu penelitian yang membahas tentang berlakunya hukum positif dan pengaruh berlakunya hukum positif terhadap kehidupan masyarakat serta pengaruh faktor-faktor non hukum terhadap terbentuknya ketentuan-ketentuan hukum.

Penelitian ini menggunakan metode pendekatan yuridis, dengan maksud untuk mengetahui perlunya dibentuk peradilan khusus Pemilukada serentak dan memformulasikan ius constituendum (cita hukum) terhadap perlunya pembentuk peradilan khusus Pemilukada serentak di Indonesia.

\section{Lokasi penelitian}

Lokasi penelitian di Kota Pekanbaru. Alasan penulis menentukan lokasi penelitian ini sehubungan dengan kompleksnya permasalahan yang dihadapi pada saat pelaksanaan Pemilukada Kota Pekanbaru pada tahun 2017 yang lalu.

\section{Populasi dan sampel}

Populasi dalam penelitian ini terdiri dari KPUD Kota Pekanbaru dan Bawaslu Provinsi Riau.Sampel dalam penelitian ini dapat dilihat padatabel berikut:

\section{Tabel}

\section{Populasi dan Sampel}

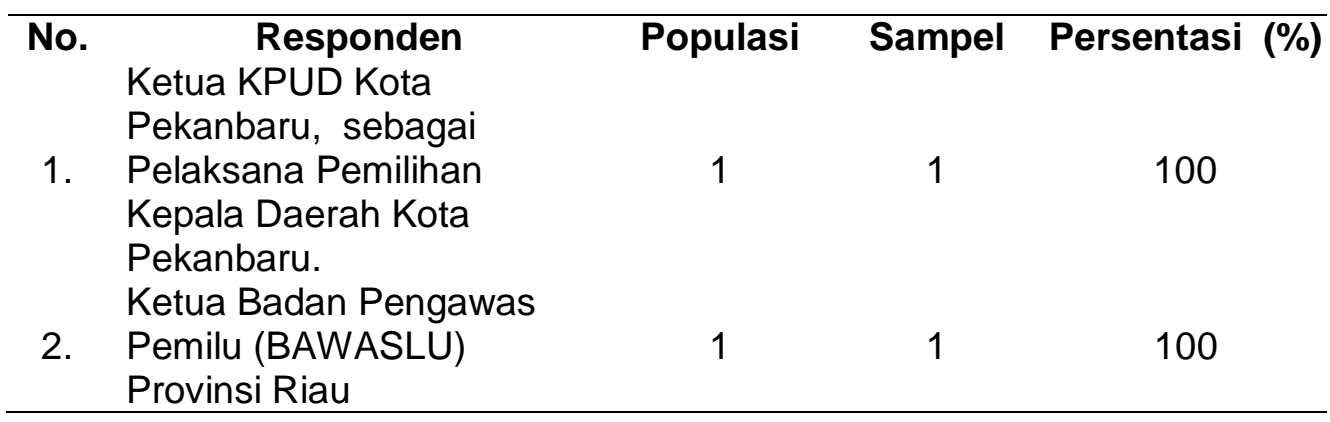




\section{Sumber data}

Sumber data dalam penelitian ini data primer, dibedakan menjadi 3 (tiga) macam :

a. Data primer, yaitu data yang diperoleh langsung dari lapangan.

b. Data sekunder, yaitu data yang diperoleh dari kepustakaan yang bersifat mendukung data primer, baik buku-buku, literatur dan peraturan perundang-undangan yang berkaitan langsung dengan penelitian ini.

c. Data tertier, yaitu data yang diperoleh melalui kamus, ensiklopedia, dan sejenisnya yang berfungsi untuk mendukung data primer dan sekunder.

\section{Teknik pengumpulan data}

Teknik pengumpulan data dilakukan dengan observasi dan wawancaraguna mengumpulkan data secara menyeluruh baik dari segi kuantitatif maupun dari segi kualitatif. Penelitian ini dilakukan terhadap objek yang berkaitan langsung dengan pokok permasalahan agar penelitian memperoleh data secara benar, obyektif, dan akurat.

\section{Analisis data}

Sebelum dilakukan analisis data, terlebih dahulu dilakukan pemeriksaan dan evaluasi untuk mengetahui validitasnya. Selanjutnya data ini dikelompokkan atas data yang sejenis untuk kepentingan analisis dalam penelitian. Eval- uasi dan penafsiran data dilakukan secara kualitatif.

Oleh karena itu, data yang sudah dikumpulkan, dipilah-pilah dan dilakukan pengolahan-nya, kemudian dianalisis dan di-tafsirkan secara logis dan sistematis dengan menggunakan metode deduktif dan induktif, sesuai dengan tujuan penelitian yang akan dicapai.

\section{Pembahasan \\ Penyelesaian Hukum Pelanggar- aan Pemilu Dalam Pemilihan Ke- pala Daerah Kota Pekanbaru Ber- dasarkan Undang-Undang Nomor 10 Tahun 2016}

Para ahli ilmu politik meyakini pemilu memiliki beberapa fungsi: Pertama, sebagai mekanisme pemilihan penyelenggara Negara. Kedua Pemilu memiliki fungsi sebagai mekanisme pendelegasian sebagian kedaulatan rakyat kepada peserta pemilu (calon anggota legislatif maupun calon pejabat eksekutif). Ketiga, pemilu sebagai mekanisme yang mampu menjamin adanya perubahan politik (sirkulasi elit dan perubahan pola dan arah kebijakan publik) secara periodik. Keempat, pemilu sebagai sarana penyelesaian konflik dengan cara memindahkan berbagai macam perbedaan dan pertentangan kepentingan yang ada di masyarakat ke dalam lembaga legislatif dan eksekutif untuk dimusyawarahkan, diperdebatkan, dan diselesaikan secara terbuka dan beradab. ${ }^{9}$

\footnotetext{
${ }^{9}$ Ramlan Surbakti, Transformasi Bawaslu dan Partisipasi Masyarakat Dalam Pengawasan Pemilu, (Jakarta: Kemitraan bagi Pembaruan Tata Pemerintahan, 2015), hlm. 7.
} 
Tetapi, penyelengaraan pemiludi Indonesia selalu menyisakan polemik. ${ }^{10}$ Khusus Pemilukada merupakan konsekuensi fundamental dalam penyelenggaraan demokrasi. Menurut Pasal 18 ayat (4) UUD 1945 pada amandemen kedua dikatakan bahwa gubernur, bupati, dan walikota masing-masing sebagai kepala pemerintah daerah provinsi, kabupaten, dan kota dipilih secara demokratis dalam setiap pelaksanaan pemilu baik itu untuk legislatif maupun eksekutif tidak terlepas dari berbagai permasahanpermasalahan yang dihadapi oleh baik oleh penyelenggara pemilu dan peserta pemilu itu sendiri

Ketika muncul undang-undang yang baru Nomor 22 Tahun 2007, pemilihan Kepala daerah bukan lagi bagian dari otonomi daerah, tetapi bagian dari Pemilu. OIeh karena itu, penyeleng-garaannya sudah langsung di bawah koordinasi KPU secara nasional dan kemudian istilah Pilkada diubah menjadi Pemilihan Umum Kepala Daerah atau disebut Pemilukada. Istilahnya yang sebelumnya (Pilkada) rezimnya Otonomi Daerah, dan yang satu (Pemilukada) rezim Pemilu.

Pemerintah mengusulkan pelaksanaan Pemilukada serentak pada 2015, 2017 dan 2019. Pada 2015 dilaksanakan Pemilukada serentak tahap pertama bagi seluruh gubernur, bupati dan wali kota yang masa jabatannya berakhir di tahun tersebut. Pemilukada serentak tahap kedua berlangsung 2018 untuk gubernur, bupati dan wali kota yang masa jabatannya berakhir tahun 2016, 2017 dan 2018.

Secara umum, perkara atau sengketa pemilu mencakup tiga ranah, yaitusengketa hasil pemilu, perkara pidana pemilu, dan sengketa administrasi pemilu. Apabila merujuk Undang-Undang Nomor 10 Tahun 2008 dan Undang-Undang Nomor 12 Tahun 2008, untuk sengketa hasil pemilu diselesaikan di MK, sedangkan penyelesaian perkara pidana pemilu diselesaikan melalui PN, sementara penyelesaian pelanggaran administrasi pemilu dlakukan oleh KPU pusat, provinsi dan kabupaten/kota berdasarkan laporan Bawaslu dan Panwaslu.

Ketersediaan mekanisme penyelesaian sengketa untuk dua persoalan pertama tentunya sudah lebih dari cukup. Artinya, semua pemangku kepentingan telah diberikan ruang untuk menyelesaikan persoalan yeng terjadi melalui MK dan peradilan umum. Sementara, pada ranah sengketa yang ketiga, masih terdapat kekosongan hukum yang dapat merugikan masyarakat maupun peserta pemilu. Salah satunya persoalan administratif yang timbul karena diterbitkannya keputusan $\mathrm{KPU}$, baik itu KPU provinsi atau kabupaten/kota yang merugikan peserta pemilu. Penyelenggaraan $\mathrm{Pe}$ milukadaKota Pekanbaru menyimpan sejumlah permasalahan. Tantangan penyelenggaraan PemilukadaKota Pekanbaru melengkapi 'noda kecil penyelenggaraan $\mathrm{Pe}$ milukada serentak tahun 2017.

\footnotetext{
${ }^{10} \mathrm{Al}$ Fajar Nugraha dan Atika Mulyandari, Pilkada Langsung dan Pilkada Tidak Langsung Dalam Perspektif Fikih Siyasah, MazahibJurnal Pemikiran Hukum Islam,Volume XV, Nomor 2, Desember 2016, hlm. 209.
} 
Dalam pelaksanaan Pemilukada serentak di Indonesia ada tiga jenis pelanggaran menurut undangundang, namun dari segi materinya, terdapat enam macam, yakni

1. Pelanggaran pidana pemilu (tindak pidana pemilu).

2. Sengketa dalam tahapan /proses pemilu, pelanggaran administrasi pemilu, pelanggaran kode etik.

3. Perselisihan hasil pemilu dan sengketa hukum lainnya.

Adapun proses penyelesaian sengketa pelanggaran PemilukadaKota Pekanbaru oleh KPU Kota Pekanbaru mengikuti mekanisme penyelesaian pelanggaran administrasi pemilihan umum sebagaimana diatur dalam Keputusan KPU Nomor 25 Tahun 2013 terkait pelaporan, pihak pelapor dan terlapor pelanggaran administrasi pemilu adalah KPU, KPU provinsi / KIP Aceh, KPU/KIP kabupaten / kota, PPK, PPS, PPLN, KPPS/KPPSLN secara berjenjang termasuk sekretariat masing-masing.

Tahapan penyelesaian dengan menerima laporan, meneliti laporan, melakukan klarifikasi, melakukan kajian dan mengambil keputusan. Sanksi hukum yang bisa dijatuhkan adalah perintah penyempurnaan prosedur, perintah perbaikan terhadap keputusan atau hasil dari proses, teguran lisan, peringatan tertulis, diberhentikan tidak dilibatkan dalam kegiatan tahapan, atau pemberhentian sementara.

Terhadap peserta pemilu yang terlambat menyampaikan laporan saldo awal dana kampanye dan laporan penerimaan dan pengeluaran dana kampanye di- kenakan sanksi, dengan membuat berita acara bagi peserta pemilu yang tidak menyerahkan laporan dan menerbitkan keputusan pemberian sanksi.

Pelanggaran administrasi pemilu adalah pelanggaran terhadap ketentuan Undang-Undang Pemilu yang bukan merupakan ketentuan pidana pemilu dan terhadap ketentuan lain yang diatur dalam peraturan KPU. Ketentuan dan persyaratan menurut Undang-Undang Pemilu tentu saja bisa berupa ketentuan-ketentuan dan persyaratanpersyaratan yang diatur, baik dalam Undang-Undang Pemilu maupun dalam keputusan-keputusan KPU yang bersifat mengatur sebagai aturan pelaksanaan dari UndangUndang Pemilu. Laporan pelanggaran administrasi pemilu disampaikan secara tertulis kepada Bawaslu, Panwaslu provinsi, Panwaslu kabupaten/kota, Panwaslu kecamatan, Pengawas Pemilu Lapangan, dan Pengawas Pemilu Luar Negeri, dengan memuat nama dan alamat pelapor, pihak terlapor, waktu dan tempat kejadian perkara, serta uraian singkat kejadian.

Dalam proses pemeriksaan doumen laporan pelanggaran administrasi pemilu KPU, KPU provinsi, dan KPU kabupaten/kota dapat menggali, mencari, dan menerima masukan dari berbagai pihak untuk kelengkapan dan kejelasan pemahaman laporan pelanggaran tersebut. Di dalam perkembangannya, Bawaslu menghendaki agar pihaknya diberi wewenang mengawasi dan sekaligus menjatuhkan sanksi administrasi itu. Hal ini kemudian direspons positif oleh legislatif dalam Undang-Un- 
dang Penyelenggara Pemilu yang baru. Aspirasi Bawaslu ini didasari pada kesulitan dalam praktik, di mana saat terjadi pelanggaran administrasi yang mestinya diselesaikan secara cepat, tidak bisa dilakukan karena proses penerusan laporan dari pengawas pemilu ke KPU /KPUD tidak segera cepat diproses dan diberi putusan serta tindakan. Hal ini disebabkan juga karena tidak ditentukannya jenis-jenis pelanggaran secara tegas dan sanksinya oleh undang-undang serta tidak adanya unit khusus di KPU/KPUD yang menerima, memproses, dan menjatuhkan sanksi administrasi. Dalam penyelesaian pelanggaran administrasi dapat dilihat sebagaimana bagan alur penganganan berikut.

\section{Bagan Penanganan Pelanggaran Administrasi}

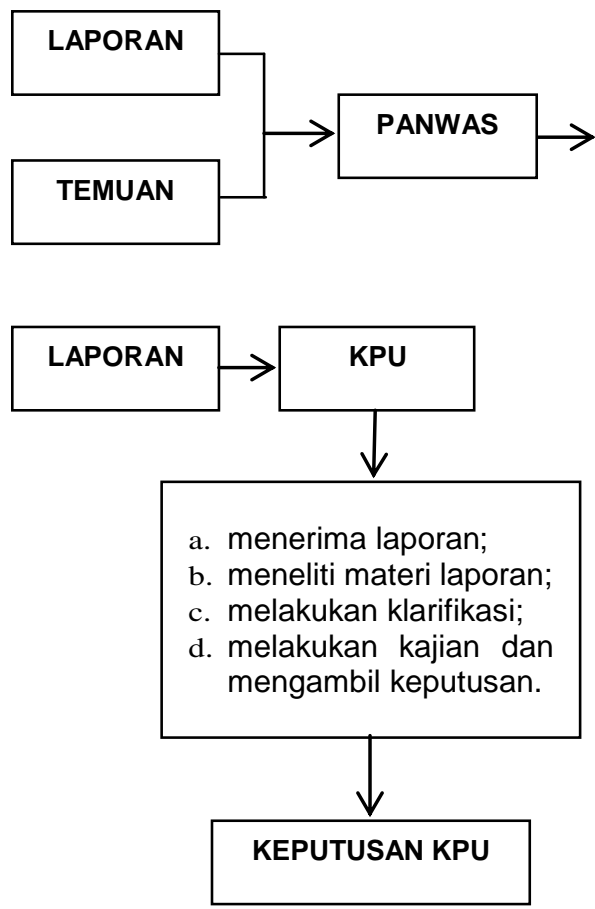

Dari bagan penanganan pelanggaran administrasi di atas dapat disimpulkan bahwa penyelesaian hukum pelanggaraan pemilu dalam Pemilukada Kota Pekanbaru berdasarkan Undang-Undang Nomor 10 Tahun 2016 selain daripada tindak pidana pemilu diselesaikan oleh KPU dan Panwaslu. Hal ini sejalan dengan hasil wawancara Peneliti dengan Ketua Panwas

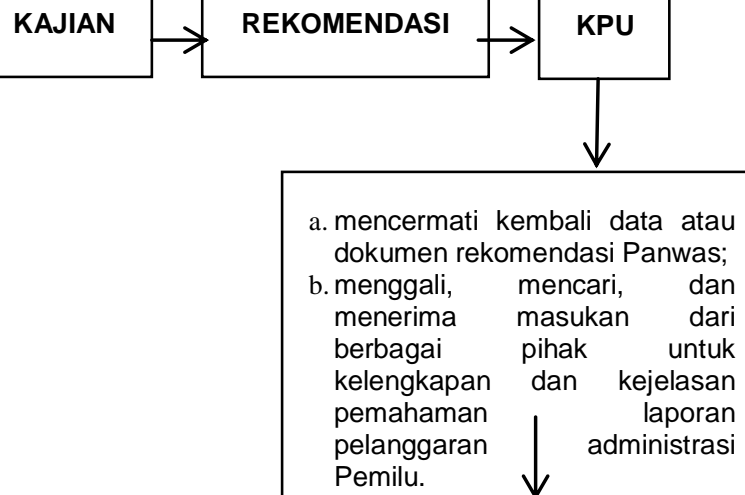

KAJIAN

a. mencermati kembali data atau dokumen rekomendasi Panwas;

b. menggali, mencari, dan menerima masukan dari berbagai pihak untuk kelengkapan dan kejelasan pemahaman laporan pelanggaran Pemilu. administrasi

Kota Peka-nbaru yang menjelaskan bahwa setiap ada temuan dan laporan dari

masyarakat sesegera mungkin ditindaklanjuti oleh Panwas dan hasil kajiannya bentuk rekomendasi disampaikan kepada KPU dan hasil rekomendasi tersebut segera diambil tindakan apakah pelanggaran 
administrasi atau ada unsur tindak pidana pemilu didalamnya. ${ }^{11}$ Apabila ada unsur tindak pidana maka direkomendasikan kepada Polri agar diproses sesuai dengan peraturan perundang-undangan yang berlaku.

\section{Hambatan Penyelesaian Hukum Pelanggaraan Pemilu Dalam Pemilihan Kepala Daerah Kota Pekanbaru}

Dalam suatu negara demokrasi, peranan lembaga penyelenggara pemilu merupakan salah satu persyaratan penting untuk mencapai pemilu yang demokratis. Selain itu, diperlukan regulasi tentang lembaga penyelenggara pemilu yang jelas agar terdapat kepastian hukum dalam hubungan checks and balances antar lembaga penyelenggara pemilu itu sendiri. Namun, hubungan yang seimbang antar lembaga penyelenggara pemilu itu sendiri tidak akan berfungsi dengan baik apabila terdapat ketidakjelasan pengaturan meng-enai lembaga penyelenggara pem-ilu itu sendiri. ${ }^{12}$

Berdasarkan wawancara dengan Ketua Bawaslu Provinsi Riau bahwa salah satu hambatan dalam penyelesaian hukum pelanggaran dalam Pemilukada Kota Pekanbaru sebagai berikut. ${ }^{13}$
1. Perangkat peraturan perundang-undangan yang memberikan kewenangan kepada KPU, Panwaslu dan Bawaslu yang tidak ada ketegasan terhadap kewenangan yang dimiliki sehinga menimbulkan ego sesama penyelenggara pemilu.

2. Minimnya koordinasi yang dibangun antara KPU dan Panwas, sehingga Panwas merasa lebih tinggi kedudukannya selaku pengawas dan bahkan merasa kewenangannya lebin besar daripada KPU.

3. Munculnya kadang riakriak intervensi dari berbagai pihak baik dari partai politik (parpol), pasangan calon (paslon) maupun tim sukses dari pasangan calon.

Untuk mengatasi hal tersebut maka perlu membangun koordinasi yang baik dan solid agar sesama penyelenggara Pemilukada tidak mudah diadu domba oleh pihakpihak yang berkepentingan dalam hal penyelenggaraaan pemilu khususnya Pemilukadaserentak di Indonesia. Seringkalipihak pihak yang berkepentingan mahir mereka-

\footnotetext{
${ }^{11}$ Wawancara dengan Indra Walid Nasution, S.H. selaku Ketua Panwas Kota Pekanbaru pada hari Kamis tanggal 5 Januari 2018 jam 11.00 Wib di kantor Panwas Kota Pekanbaru di Jalan Elang No. 6 Kelurahan Kampung Melayu Kecamatan Sukajadi Kota Pekanbaru.

${ }^{12}$ Lusy Liany,Desain Hubungan Kelembagaan Penyelenggara Pemilihan Umum, Jurnal Cita Hukum, Volume 4, Nomor 1, Juni 2016, hlm. 52.

${ }^{13}$ Wawancara dengan Edy Syarifudin, S.Ag selaku Ketua Bawaslu Provinsi Riau pada hari Rabu, tanggal 3 Januari 2018 jam 10.30 Wib di Kantor Bawaslu Provinsi Riau Jalan Sultan Syarif Kasim Nomor 119 Kota Pekanbaru.
} 
yasa sesuatu masalah yang kecil menjadi seolah-olah masalah yang sangat besar akibat kepentingan pihak-pihak tertentu tersebut.

\section{Upaya yang dilakukan Dalam Penyelesaian Hukum Pelanggara- an Pemilu Dalam Pemilihan Kep- ala Daerah Kota Pekanbaru}

Berdasarkan hasil wawancara peneliti dengan Amiriddin Sijaya selaku Ketua KPU Kota Pekanbaru bahwa upaya yang dapat dilakukan oleh baik KPU, Panwaslu dan Bawaslu dalam penyelesaian hukum pelanggaran Pemilu dengan cara membangun koordinasi yang baik sesama unsur penyelenggara pemilu antara lain KPU, Panwas dan Bawaslu. Tidak terlepas juga koordinasi dengan pihak Kepolisian dan Kejaksaan, oleh karena ketika terjadi tindak pidana pemilu tentunya tidak terlepas dari kewenangan aparat kepolisian dan kejaksaan dalam melakukan penegakan hukum tindak pidana dibidang pemilu. ${ }^{14}$

Beliau juga berpendapat bahwa jika pengadilan khusus Pemilukadaserentak merupakan bagian terpenting dalam mengawal proses demokrasi, tujuannya untuk memproteksi hak konstitutional warga negara dan peserta pemilihan umum, untuk memberikan ruang hukum kepada pihak-pihak yang dirugikan dalam penyelenggaraan Pemilukada serentak untuk mendapatkan kepastian hukum dalam kehidupan negara demokrasi, sekaligus sebagai upaya untuk mempercepat penyelesaian sengketa atau kasus-kasus selama proses pemilihan umum berlangsung. Untuk "kepastian hukum", bagi penyelenggara pemilu, pengawas pemilu, pemantau pemilu dan peserta mulai dari proses tahapan, program dan jadwal waktu penyelenggaran pemilu.

Apabila ada pihak-pihak yang belum puas atas hasil kerja yang diberikan oleh KPU sebagai penyelenggara pemilu, dapat mengajukan sengketanya di pengadilan khusus pemilu.

\section{Simpulan}

Penyelesaian hukum pelanggaraan pemilu dalam Pemilukada Kota Pekanbaru selain daripada tindak pidana pemilu diselesaikan oleh KPU dan Panwaslu.Setiap ada temuan dan laporan dari masyarakat sesegera mungkin ditindaklanjuti oleh Panwaslu dan hasil kajiannya bentuk rekomendasi disampaikan kepada KPU. Hasil rekomendasi tersebut segera diambil tindakan apakah pelanggaran administrasi atau ada unsur tindak pidana pemilu didalamnya. Apabila ada unsur tindak pidana pemilu maka direkomendasikan kepada Polri agar diproses

1. sesuai dengan ketentuan peraturan perundang-undangan yang berlaku.

2. Hambatan penyelesaian hukum pelanggaran pemilu dalam Pemilukada Kota Pekanbaru adalah perangkat Panwaslu sehingga nebimbulkan ego sesame penyelenggara

\footnotetext{
${ }^{14}$ Amiriddin Sijaya selaku Ketua KPU Kota Pekanbaru pada hari Kamis, tanggal 4 Januari 2018 jam 10.30 Wib di Kantor KPU Kota Pekanbaru.
} 
pemilu. Minimnya koordinasi yang dibangun antara KPU dan Panwas, sehingga Panwas merasa kewenangannya lebih besar daripada KPU. Munculnya riak-riak intervensi dari berbagai pihak yang berkepentingan.

3. Upaya yang dilakukan dalam penyelesaian hukum pelanggaraan Pemilukada Kota Pekanbaru dengan cara membangun koordinasi yang baik sesama unsur penyelenggara pemilu, yaitu KPU, Pan-was dan Bawaslu.

\section{Saran}

1. Untuk mewujudkan penyelenggaraan Pemilukadayang berkualitas dan memiliki integritas tinggi maka perlu dilakukan penyempurnaan terhadap aturan yang telah ada melalui penambahan aturan, penegasan maksud dan sinkronisasi antar peraturan perundang-undangan yang telah ada salah satu diantaranya melalui pembuatan instrumeninstrumen komplain atas terjadinya pelanggaran pemilu yang lengkap, mudah diakses, terbuka, dan adil. Lebih penting lagi memastikan bahwa aturan main yang ditetapkan tersebut dijalankan secara konsisten oleh semua pihak baik penyelenggara, peserta dan masyarakat.

2. Tersedianya aturan yang konkrit dan implementatif penting untuk menjamin kepastian dan keadilan hukum sehingga pemilu memiliki landasan legalitas dan legitimasi yang kuat sehingga pemerintahan yang dihasilkan melalui pemilu tetap mendapatkan dukungan masyarakat luas. Untuk itu, maka segala pelanggaran yang terjadi dalam proses pelaksanaan pemilu harus diselesaikan secara adil, terbuka dan konsisten.

3. Alangkah baiknya jika pengadilan khusus Pemilukada serentak merupakan bagian terpenting dalam mengawal proses demokrasi, tujuannya untuk memproteksi hak konstitutional warga negara dan peserta pemilihan umum, untuk memberikan ruang hukum kepada pihak-pihak yang dirugikan dalam penyelenggaraan Pemilukada serentak untuk mendapatkan kepastian hukum dalam kehidupan negara demokrasi, sekaligus sebagai upaya untuk mempercepat penyelesaian sengketa atau kasus-kasus selama proses pemilihan umum berlangsung. Untuk "kepastian hukum",bagi penyelenggara pemilu, pengawas pemilu, pemantau pemilu dan peserta mulai dari proses tahapan, program dan jadwal waktu penyelenggaran pemilu.

\section{Referensi}

Al Fajar Nugraha dan Atika Mulyandari. Pilkada Langsung dan Pilkada Tidak Langsung Dalam Perspektif Fikih Siyasah. Mazahib. Jurnal Pemikiran Hukum Islam. 
Volume XV. Nomor 2. Desember 2016.

Arif Ramadhan Sy. Implikasi Undang-Undang Nomor 8 Tahun 2015 tentang Perubahan Atas Undang-Undang Nomor 1 Tahun 2015 tentang Penetapan Peraturan Pemerintah Pengganti Undang-Undang Nomor 1 Tahun 2014 tentang Pemilihan Gubernur, Bupati, dan Walikota Menjadi Undang-Undang Terhadap Penyelesaian Sengketa Hasil Pemilihan Kepala Daerah di Mahkamah Konstitusi, Implikasi Undang-Undang Nomor 8 Tahun 2015 tentang Perubahan Atas Undang-Undang Nomor 1 Tahun 2015 tentang Penetapan Peraturan Pemerintah Pengganti Undang-Undang Nomor 1 Tahun 2014 tentang Pemilihan Gubernur, Bupati, dan Walikota Menjadi Undang-Undang Terhadap Penyelesaian Sengketa Hasil Pemilihan Kepala Daerah di Mahkamah Konstitusi.JOM Fakultas Hukum. Volume III. Nomor 2. Oktober 2016.

Herdi Munte Mirza Nasution et.al. Penyelesaian Sengketa Administrasi Pemilihan Kepala Daerah Berdasarkan Undang-Undang Nomor 8 Tahun 2015 tentang Pemilihan
Gubernur Bupati dan Walikota (Studi Putusan Sengketa Administrasi Pemilihan Walikota dan Wakil Walikota di Panwas Kota Pematangsiantar Tahun 2015. USU Law Journal. Volume 5. Nomor 1. Januari 2017.

Khairul Fahmi. Menimbang Pengadilan Khusus Pemilu. Majalah Mahkamah Konstitusi. Nomor 40. Mei 2011.

Lusy Liany.Desain Hubungan Kelembagaan

Penyelenggara

Pemilihan Umum, Jurnal Cita Hukum. Volume 4. Nomor 1. Juni 2016.

Refki Mukhliza. Pemilihan Umum Kepala Daerah di Kabupaten Pasama Tahun 2010. Artikel. Program Magister IImu Hukum Pascasarjana Universitas Bung Hatta Padang. 2014.

Ramlan Surbakti. 2015. Transformasi Bawaslu dan Partisipasi Masyarakat Dalam Pengawasan Pemilu. Jakarta: Kemitraan bagi Pembaruan Tata Pemerintahan.

Yusri Munaf. Implikasi Pemilihan Kepala Daerah Serentak Pada Tahun 2016 Dalam Perkembangan Demokrasi di Indonesia.Asian Journal of Environment, Volume 1. Issue 1. September 2017. 
Zahirman, Penerapan Asas Jujur Dalam Pelaksanaan

Pemilihan Umum

Walikota Pekanbaru ditinjau dari UndangUndang Nomor 32 Tahun 2004. Jurnal PPKN \& Hukum. Volume 10. Nomor 1. April 2015.
Zuli Afrianto. Analisis Peran Aktor Pada Pemilu Kepala Daerah Kota Bandar Lampung /Periode 2010 -2015. Tesis. Magister Ilmu Pemerintahan. Pro gram Pascasarjana Magister Ilmu Pemerintahan Fakultas IImu Sosial dan IImu Politik. Universitas Lampung, 2013. 